\title{
Coconut Carbon Sequestration Part 1 / Highlights on Carbon Cycle in Coconut Plantations
}

\author{
O. Roupsard ${ }^{1,2}$, N. Lamanda ${ }^{1,2}$, C. Jourdan ${ }^{1}$, M. Navarro ${ }^{2}$, I. Mialet-Serra ${ }^{1}$, \\ J. Dauzat ${ }^{1}$, Tiata Sileye ${ }^{2}$
}

\begin{abstract}
How to collect relevant scientific information for preparing the application of a coconut Clean Development Mechanism CDM-C sink (afforestation or reforestation) project? What is the theory and how to describe the $\mathrm{C}$ cycle within a coconut plantation, separating the coconut trees, the under-storey and the soil? Where do coconut trees store their $\mathrm{C}$ ? What is the fate of this $\mathrm{C}$ in the whole ecosystem: is it allocated to permanent structures of the standing biomass or to non-permanent organs (then to litter and then to the soil organic matter, SOM)? What would be the range for $\mathrm{C}$ sequestration by coconut plantations? Do coconut plantations fix C (speed of fixation) and store (stock of C) more or less than tropical humid forests? Regarding the stocks, a key issue for CDM is to store more $\mathrm{C}$ than the baseline scenario (initial ecosystem of reference), hence what are the types of initial ecosystems likely to allow $\mathrm{C}$ storage after coconut cultivation? How are management techniques (for planting and for using the litter) supposed to influence the $\mathrm{C}$ fixation?

This study reviews recent reports from the literature about the $\mathrm{C}$ cycle (stocks and fluxes) of a chronosequence of plantations, considered to be a reference (high level of fertility, no drought). It gives figures for the potential $\mathrm{C}$ balance of a coconut plantation. Although the results should not be extrapolated without using at least validation in other situations and also using transfer models for taking account biophysical and cultivation conditions, they already highlight some main traits of this peculiar crop. Moreover, they bring new insights into the physiology of this plant, which of high interest for understanding the components of yield. They also show that litter management is crucial for the $\mathrm{C}$ fixation and the sustainability of coconut cultivation, especially when the levels of inputs are low. Using windrows (where coarse debris are disposed) creates like an "island of fertility for the coconut sustainability", allowing the trees to feed and also to survive during difficult climate conditions (e.g. drought periods).
\end{abstract}

Keywords: C balance / Productivity / C allocation / Litter / Soil Organic Matter / Cocos nucifera L.

\footnotetext{
${ }^{1}$ Centre for International Cooperation in Agricultural Research for Development (CIRAD), BP 34032 Montpellier Cedex 1, France.

2 Vanuatu Agricultural Research and Technical Center (VARTC), BP 231, Espiritu Santo, Vanuatu. Corresponding author: Olivier Roupsard. Email: roupsard@ cirad.fr
} 


\section{Introduction}

Land-use changes under the tropics account for $20 \%$ of global greenhouse gas (GHG) emissions (IPCC 2007). Productivity and carbon balance of each type of land use are key issues for Clean Development Mechanism (CDM), particularly under the tropics. In addition, the impact of crop management on GHG emissions might become an issue under the second period of commitment of the CDM (>2012).

Ecosystem productivity is generally referred to by Net Primary Productivity (NPP: the sum of annual growth and mortality), Gross Primary Productivity (GPP: $\mathrm{CO}_{2}$ entry in the ecosystem by photosynthesis) or else Net Ecosystem Productivity (NEP: $\mathrm{CO}_{2}$ balance of the ecosystem, in other words, the $\mathrm{C}$ sequestration if we neglect the other GHG). A table of abbreviations in proposed in Appendix 1.

Below, we will sum up some recent scientific results about the productivity, the $\mathrm{C}$ cycle, the $\mathrm{C}$ balance from a coconut plantation growing in optimum conditions (high fertility, no drought, high yielding hybrid, optimum age for production, i.e. around $20 \mathrm{YAP}$ ), and of a chronosequence (using also smallholders' plantations of tall coconut) in order to highlight the main traits of the $\mathrm{C}$ cycle of coconut plantations, including coconut trees, herbaceous under-storey and soil. We will stress the compartments where $\mathrm{C}$ should be monitored during CDM-C sink projects.

\section{Reminders on the theory of $\mathrm{C}$ cycle in plantations}

The figure 1 illustrates the main fluxes involved in the carbon cycles in forest ecosystems (Saint-André et al. 2007).

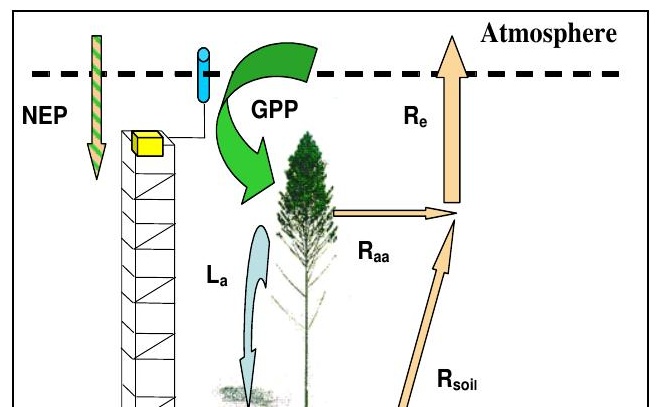

Figure 1: The carbon cycle in forest ecosystems. Brown arrows represent upward $\mathrm{CO}_{2}$ fluxes (autotrophic respiration $\left(\mathrm{R}_{\mathrm{a}}\right)$ from above- and below-ground plant compartment, $\left(\mathrm{R}_{\mathrm{aa}}\right)$ and $\left(\mathrm{R}_{\mathrm{ar}}\right)$, heterotrophic respiration $\left(\mathrm{R}_{\mathrm{h}}\right)$ and ecosystem respiration $\mathrm{R}_{\mathrm{e}}=\mathrm{R}_{\mathrm{a}}+\mathrm{R}_{\mathrm{h}}$ ). Green arrows represent downward $\mathrm{CO}_{2}$ fluxes (gross primary production, GPP). Net ecosystem respiration (NEP) is usually a downward flux (sequestration), except in certain situations (after clear-cutting for example) when $\mathrm{R}_{\mathrm{e}}$ may exceed GPP. Blue arrows represents ecosystem internal fluxes of carbon due to litter fall $\left(\mathrm{L}_{\mathrm{a}}\right)$ and belowground litter production by fine root turnover $\left(\mathrm{L}_{\mathrm{r}}\right)$. Losses of carbon by volatile organic compounds (VOC) emission, or by dissolved organic carbon (DOC) leaching have been neglected and are therefore not represented.

If there are no inputs from organic fertilizers, all the carbon inputs come from the gross primary production (GPP: the sum of the photosynthesis of the plants of the ecosystem). A significant part of this carbon uptake is lost through autotrophic respiration (i.e. plant respiration, $\mathrm{R}_{\mathrm{a}}$ ) which can be arbitrarily divided into two main components: root respiration, $\left(\mathrm{R}_{\text {ar }}\right)$ and respiration from aboveground $\left(\mathrm{R}_{\mathrm{aa}}\right)$ plant compartments (leaves, branches, stems). The fraction of GPP that is not lost through plant respiration is used to produce new biomass, thus contributing to the Net Primary Production (NPP: the sum of visible growth + litter production):

$$
N P P=G P P-R_{a} \quad \text { Eq. } 1
$$

Allocation of NPP to the different plant compartments contributes to tree growth and litter production (L). Among the various plant 
compartments, we may distinguish between compartments with high turnover rate (fruits, peduncles, leaves, fine roots), contributing to litter production, and compartments with low turnover rate (stem, coarse roots), contributing mostly to biomass accumulation. The stand growth (carbon accumulation in biomass $\Delta \mathrm{C}_{\mathrm{B}}$ is the difference between NPP and L:

$$
\Delta C_{B}=N P P-L
$$

Eq. 2

Litter inputs to the soil are decomposed by soil microorganisms. The part that is not oxidized is transferred to the soil organic matter (SOM) pool. Emission of $\mathrm{CO}_{2}$ through litter decomposition and subsequent SOM oxidation by soil microorganisms both contribute to the socalled 'heterotrophic respiration' $\left(\mathrm{R}_{\mathrm{h}}\right)$.

A proportion of the litter produced through NPP is thus lost through heterotrophic respiration. The difference between the rate of NPP and $R_{h}$ controls the rate of net ecosystem production NEP), which is defined by (see also Fig. 2):

$$
N E P=N P P-R_{h}=\Delta C_{B}+\Delta C_{S}+\Delta C_{L} \quad \text { Eq. } 3
$$

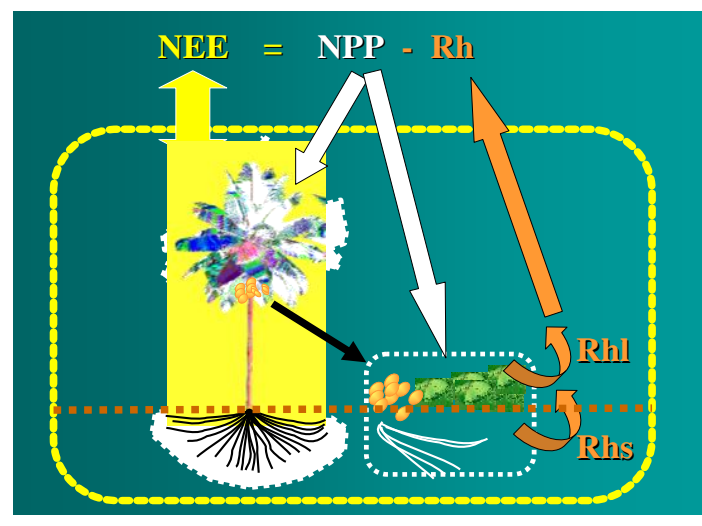

Figure 2: Partitioning of the $\mathrm{C}$ balance of the coconut plantation (NEP) into net primary productivity (NPP) and heterotrophic respiration $\left(\mathrm{R}_{\mathrm{h}}\right)$.

The total respiratory carbon loss by the ecosystem ( $\mathrm{R}_{\mathrm{e}}$ : ecosystem respiration) results from plant respiration $\left(R_{a}\right)$ and respiration of soil and litter decomposers $\left(\mathrm{R}_{\mathrm{h}}\right)$. The net ecosystem exchange of $\mathrm{CO}_{2}$ between the forest and the atmosphere (NEE) is the difference between $\mathrm{CO}_{2}$ uptake through photosynthesis, and $\mathrm{CO}_{2}$ emission through ecosystem respiration. This net flux is highly variable both diurnally (due to variations of light, temperature, and air relative humidity), and seasonally, but it can be monitored continuously with the eddycovariance methodology, and cumulated over time for estimating monthly or annual Net Ecosystem Production:

$$
N E P=G P P-R_{e}=G P P-R_{a}-R_{h}=\sum N E E \quad \text { Eq. } 4
$$

According to equation 4, the variations of C stocks in soil + biomass + necromass (litter) account for $\mathrm{C}$ sequestration (Stock Method). However, the main impediment is to cope with the large variability of soil $\mathrm{C}$ stock when measurement is desired, either intra-plot or between plots. A synchronic approach, using chronosequences (or time series), is proposed here for estimating the $\mathrm{C}$ sequestration on the long term. However, there are no methods accurate enough to measure soil $\mathrm{C}$ stocks variations on the short term (a few years).

On the other hand, for the short term (from minutes to a few years), the Flux Method is proposed, using direct measurements of the fluxes above the canopy, using eddy-covariance methods (Fig. 3).

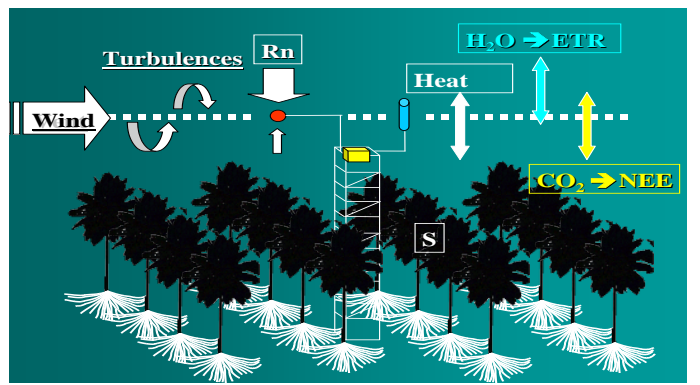

Figure J: iviedsuring hie iluxes oi $\mathcal{L}_{2}, \boldsymbol{\Pi}_{2} \mathrm{U}$ and energy above a plantation of coconut by eddycovariance, using a flux-tower, where $R_{n}$ is the net radiation, ETR the evapo-transpiration and $S$ the stock of heat.

The Flux Method by eddy-covariance (or flux towers) was developed only recently, in the late 1990's as a tool for assessing the ecosystem $\mathrm{C}$ balance. The methods were standardized and a net of experiments has been displayed on various types of World terrestrial ecosystems (over 250, 
under the umbrella of Fluxnet: http://daac.ornl.gov/FLUXNET/). Tropical ecosystems remain scarce, especially for tropical planted perennials nearly absent (Cirad has displays on eucalypt, rubber tree, coconut, coffee though), and detailed site information can be found on Fluxnet. Only few displays include chronosequences, although this is required for estimating the $\mathrm{C}$ sequestration on the long term.

Both methods (Stock and Flux) should ideally complete or cross-validate each-other.

\section{Preparing scientific information for a CDM-C sink application in coconut plantations}

All the policy part of this question was reported in the companion paper (Part 2). Scientific measurements of $\mathrm{C}$ sequestration (e.g. $\mathrm{C}$ stocks in chronosequences; $\mathrm{CO}_{2}$ fluxes by eddy-correlation; GHG emissions by various methods) are not actually required for any application to CER. Simple surveys for the baseline and estimations from available literature are generally sufficient to meet the methodologies approved by UNFCCC (http://cdm.unfccc.int/Statistics/). However, considerable advantages result from scientific approaches of $\mathrm{C}$ sequestration, especially for coconut plantations, due to the peculiar mode for C allocation:

More pools of $\mathrm{C}$ can eventually be taken into account in the computation of sequestration. A major impediment here is that, contrary to dicot trees, coconut does not allocate much of its $\mathrm{C}$ into permanent structures (stems, coarse roots), but allocates more than $86 \%$ into perishable structures (fruits, leaves, peduncles, fine roots) that will quickly turn into litter, and be respired by the ecosystem or contribute to the build-up of Soil Organic Matter (SOM). This "litter-oriented" fate of $\mathrm{C}$ is very peculiar, and cannot be accounted properly using regular forestry inventories of $\mathrm{C}$ sequestration, such as simple evaluation of $\mathrm{C}$ build up in the stems: it will certainly require detailed studies of $\mathrm{C}$ accumulation in the SOM, in addition to the $\mathrm{C}$ accumulated in the biomass and in the necromass (litter).

- Reducing the standard deviation in the measurement of the $\mathrm{C}$ stock (soil, roots, using appropriate scientific methods) may help demonstrate statistically a $\mathrm{C}$ sink and gain CER, or alternatively demonstrate that one compartment can be neglected (costs reduced).

- Understanding the fate of $\mathrm{C}$ is central in the questions of fertility, growth, productivity, sustainability, energy and hence profitability and environment,

- $\quad$ Alternative management of the fertility is key to sustainable development.

- Functional models can be used for simulating the impact of alternative situations (management practices, climate, resources).

- Management practices are candidate to $\mathrm{CDM}$ for the second commitment period (>2012) and should be documented.

\section{Materials and Methods}

\section{C balance of a coconut plantation}

The coconut $\mathrm{C}$ sequestration was assessed on a chronosequence of coconut plantations, placed in optimal conditions (high fertility, no drought, high yielding hybrid VRD x VTT) in VARTC between 2001 and 2007, Santo, Vanuatu, all located within a 450 ha unit (Fig. 4) and tall coconuts from smallholder's plantations (VTT) in an adjacent island with similar conditions (Malo). The stands were all surveyed for C stocks. NEP was assessed in only one stand (around 20 years old) for $\mathrm{C}$ flux by eddycovariance.

The Stock Method is not really standardized in the literature, especially not for coconut plantations with two layers (coconut + grass under-storey) or more vertical layers of vegetation in smallholders plots (coconut trees + fruits trees + grass under-storey). It should be adapted to the system under observation (e.g. soil horizontal and vertical variability, 
management, plant phenology, plant compartments, etc.). Navarro et al. (2008) proposed adjusted methods for assessing NPP in coconut plantations (growth and litter production of coconut and grass under-storey), aboveground and also below-ground. The belowground compartment was clearly the biggest challenge. We also used NIRS (Near Infrared Reflectance Spectrometry) in order to assess soil $\mathrm{C}, \mathrm{N}$ and organic matter stocks on a large sampling basis (Lamanda et al. 2004a), and after due calibration. Flux methods were reported by Roupsard et al. $(2006$; 2007a) and Luyssaert et al. (2007).

The initial stage is crucial in the $\mathrm{C}$ sequestration result. Our initial ecosystem was a high secondary forest, with a putative large C stock in soil and biomass. Our hypothesis was that the $\mathrm{C}$ stock would be depleted after felling the forest and that the sequestration would be negative. However, it was important to assess $(i)$ what was the initial loss after planting, (ii) if a partial repletion, stagnation or decrease would be observed during the lifespan of the coconut plantation. This might indicate eventually if, starting from an initial ecosystem displaying a low stock, like for example semi-abandoned areas or old coconut plantations, the young coconut plantation would eventually be a good candidate for increasing the $\mathrm{C}$ stock, which is the focus of the CDM. In this case, the type of management during coconut planting might be of crucial importance in order to minimize the initial C losses.

\section{Soil Organic Matter and ecosystem C stock trends along a coconut chronosequence}

A survey of the soil organic matter (SOM) in the top soils of fertile areas of Vanuatu has been implemented on chronosequences from 0 to 50 years after coconut planting, including an initial stage of secondary forest, various coconut-based smallholders' cropping systems in the island of Malo (Lamanda et al. 2004b) and large plantations in VARTC-Santo. For example, on smallholders plots, SOM of $12 \%$ in top soil $(0-20 \mathrm{~cm})$ and $5 \%$ in sub soil $(20-35 \mathrm{~cm})$ were measured with an average value of the Corg/Nitrogen ratio of 10 (Lamanda et al. 2004a). Also, the whole ecosystem C stock was estimated along the chronosequence, and compared to the initial stage.

\section{Results and Discussion}

The measurements and outputs of models presented here are valid only locally for the real experimental conditions and must be considered as a case-study. Extrapolation should not be done without extreme caution. Modelling would be a key step before extrapolation.

\section{Net Primary Productivity (NPP)}

As reported in Navarro et al. (2008), NPP includes the annual biomass and litter production of the coconut and the grass under-storey, with the distribution presented in Fig. 5 and a total NPP of $32 \mathrm{t}_{\mathrm{DM}} \mathrm{ha}^{-1} \mathrm{yr}^{-1}$, of which, around half is assumed to be $\mathrm{C}\left(16 \mathrm{tC} \mathrm{ha}^{-1} \mathrm{yr}^{-1}\right)$. For the sole coconut trees, NPP was $12 \mathrm{tC} \mathrm{ha}^{-1} \mathrm{yr}^{-1}$. Nut production represented $46 \%$ of that productivity. Copra yield was $2.7 \mathrm{t}_{\mathrm{DMcopra}} \mathrm{ha}^{-1} \mathrm{yr}^{-1}$.

Figure 4: Diagram of the Cocoflux experiment of assessing $\mathrm{C}$ sequestration at the scale of a chronosequ (VRD x VTT), starting from an initial secondary forest.

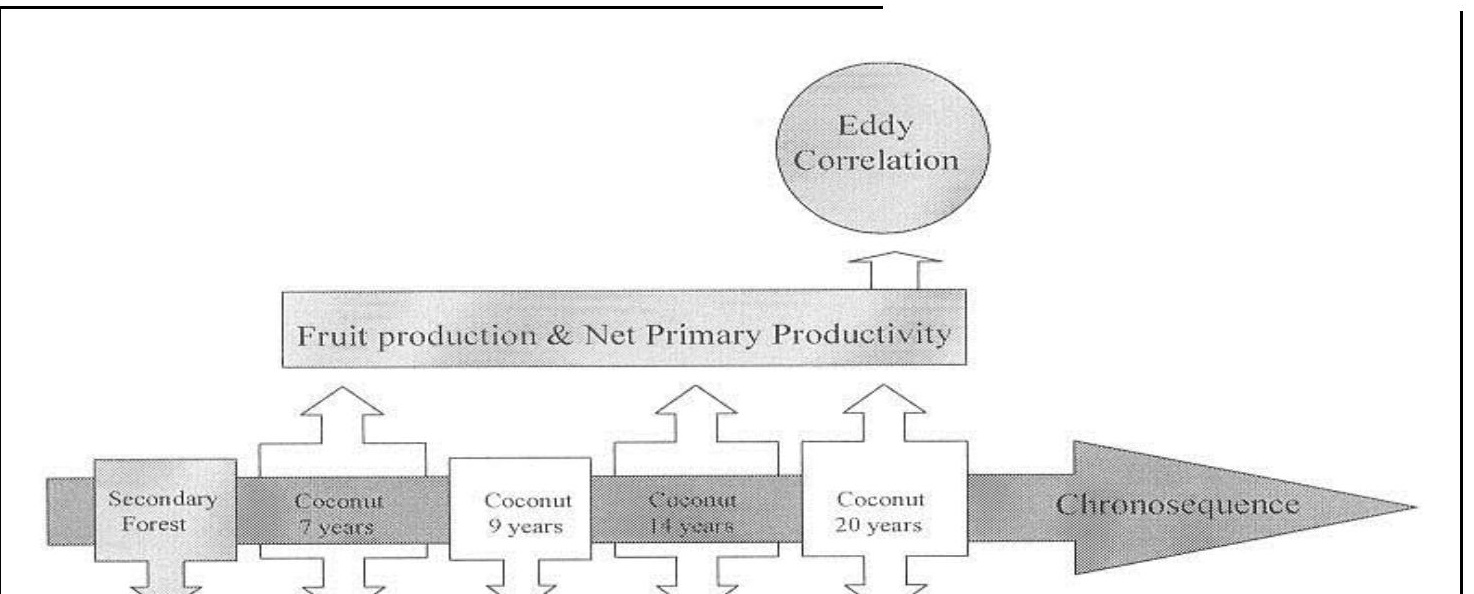


Figure 5: Net Primary Productivity (NPP) of the plantation Stand (coconut + grass) assessed by monitoring the growth rate of each compartment around 20 years after plantation. Cocoflux experiment of VARTC, Santo, Vanuatu, optimal conditions.

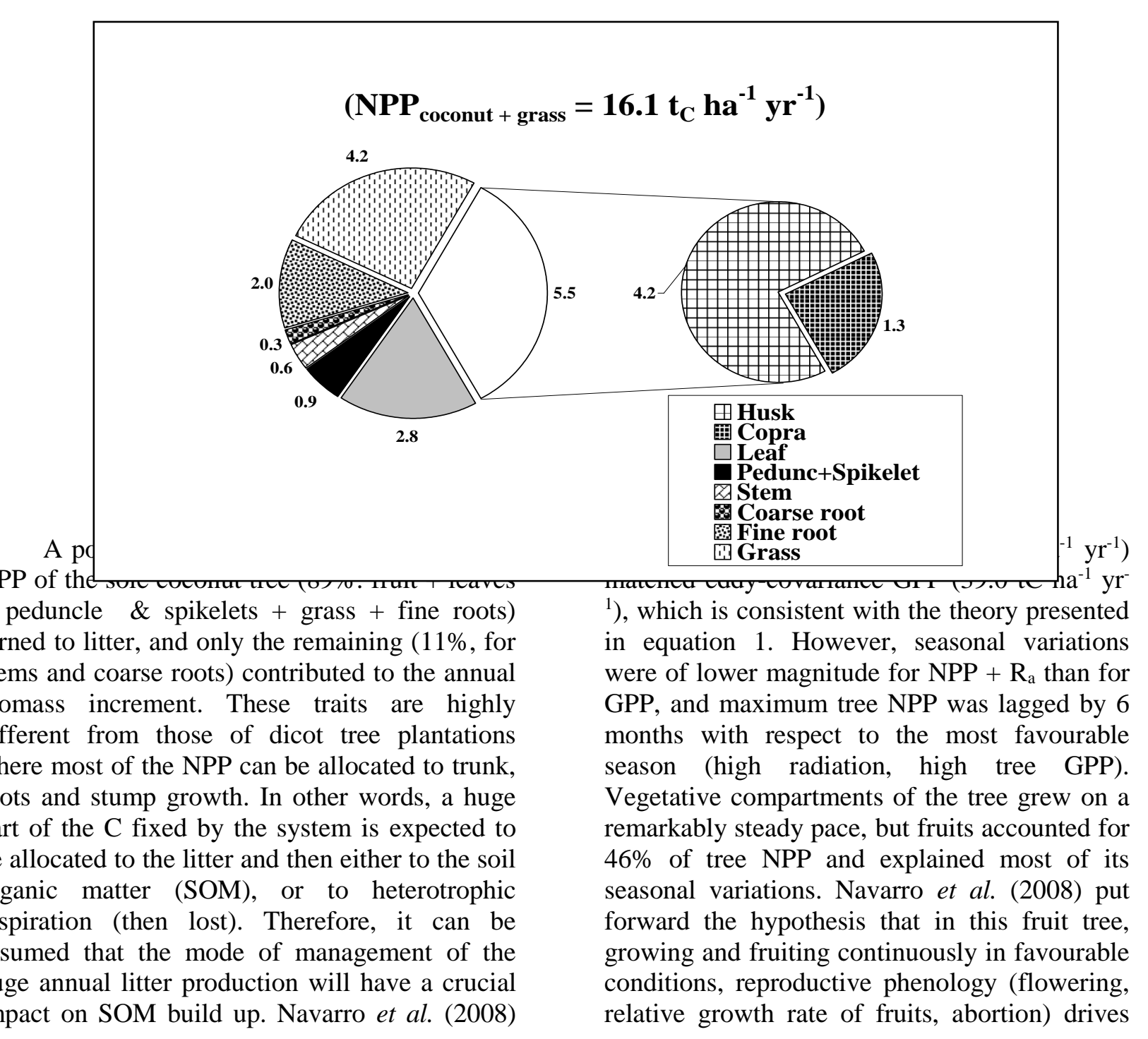


the seasonality of NPP more directly than its photosynthesis.

\section{Net Ecosystem Productivity (NEP), as compared to tropical forests}

Roupsard et al. (2007) reported that a tropical plantation of coconut tree with a grass under-storey (total LAI of around 6 for the two layers) and placed in close-to-optimum growing conditions (high level of fertility, no seasonal drought, evergreen, continuous growth) displayed productivity (GPP and NPP) characteristics close to tropical evergreen humid forests, i.e. amongst the highest levels encountered in global forest biomes (Luyssaert et al., 2007). Climate, fertility, LAI and phenology appeared to be key elements for ranking productivity of ecosystems, irrespective of their status (from artificial to natural). This is an appealing result, notably for other tropical perennial crops grown in fertile conditions and in absence of drought, such as e.g. oil palm, coffee, rubber tree. It would deserve further investigations, together with other annual tropical crops.

Roupsard et al. (2007) reported also a three-year average apparent NEP (the actual ecosystem $\mathrm{C}$ balance for the coconut plantation), being $8.1 \mathrm{tC} \mathrm{ha}^{-1} \mathrm{yr}^{-1}$ (Tab. 1) to be compared with the average $4 \mathrm{tC} \mathrm{ha}^{-1} \mathrm{yr}^{-1}$ reported by Luyssaert et al. (2007) for tropical humid evergreen forests. Both results range by a factor of 2. They interpreted a higher $\mathrm{C}$ storage in the coconut plantation in two ways: first, part of the NPP of the coconut plantation was actually exported every 2 months out of the plantation (copra from the nuts) and thus did not contribute to $\mathrm{R}_{\mathrm{e}}$ : this amounted to around $1.3 \mathrm{tC} \mathrm{ha}^{-1} \mathrm{yr}^{-1}$, hence reducing the apparent NEP to a corrected NEP of $6.8 \mathrm{tC} \mathrm{m}^{-2} \mathrm{yr}^{-1}$. Second, the coconut plantation was very young (19-21 year-old) in comparison with the natural forests, and was thus likely further from equilibrium between GPP and $\mathrm{R}_{\mathrm{e}}$ than mature forests.

Copra is always exported and contributes by $11 \%$ to NPP of coconuts palms, so its contribution has to be accounted for in the final $\mathrm{C}$ balance.
Table 1: Net Ecosystem Productivity (NEP or ecosystem $\mathrm{C}$ balance) of the coconut plantation during 3 consecutive years, 2001 to 2003, in conditions where only copra is exported and all the rest of litter left inside the plantation. Positive values mean here that $\mathrm{C}$ is being retrieved from the atmosphere and stored into the plantation. Cocoflux experiment of VARTC, Santo, Vanuatu, optimal conditions.

\begin{tabular}{|l|c|}
\cline { 2 - 2 } \multicolumn{1}{c|}{} & $\mathrm{tC} \mathrm{ha}^{-1} \mathrm{yr}^{-1}$ \\
\hline $\begin{array}{l}\text { Apparent NEP } \\
\text { (average of 3 years) }\end{array}$ & 8.1 \\
\hline Copra exported & 1.3 \\
\hline Corrected NEP & 6.8 \\
\hline
\end{tabular}

\section{Coconut tree reserves}

Mialet-Serra et al. (2005) reported that the average stock of non-structural carbohydrates (mainly sucrose reserves) in the coconut tree would amount to around $25 \mathrm{~kg}$ per tree (at around 20 YAP), i.e. around $8 \%$ of their standing biomass. The physiological function of the large amounts of sucrose stored mainly in its stem is not known. However, reserve storage or de-storage might play a major role in explaining intra-annual schedule in NPP, allowing NPP to become rather independent from the seasonal fluctuations of the $\mathrm{C}$ supply (GPP). The reserve dynamics were reported by (Mialet-Serra et al. 2008). They investigated the dynamics of dry matter production, yield and yield components and concentrations of non-structural carbohydrate reserves. The underlying hypothesis was that reserve storage and mobilization enable the crop to adjust to variable sink-source relationships at the scale of the whole plant. Sink-source imbalances were partly compensated by transitory reserve and more importantly by variable light-useefficiency in the short term, and by adjustment of fruit load in the long term.

Managing coconut litter for enhancing soil organic matter and helping sustainable development 


\section{Horizontal and vertical variability of SOM content}

The horizontal and vertical variability of SOM in one coconut plantation + grass, aged 20 years old (eddy-covariance plot) after felling the forest and planting has been assessed in VARTCSanto (unpublished results). The horizontal variability was assessed corresponding to the general pattern of one windrow (coarse debris accumulated), one row and one clear inter-row. We observed highly significant effects for horizontal and vertical gradients. On top, $\mathrm{C}$ contents were $0.038 \mathrm{gC} \mathrm{cm}_{\text {soil }}{ }^{-3}\left(0.0039 \mathrm{gN} \mathrm{cm}_{\text {soil }}{ }^{-}\right.$ ${ }^{3}$ for nitrogen). They decreased exponentially till $100 \mathrm{~cm}$, reaching $0.005 \mathrm{gC} \mathrm{cm}_{\text {soil }}{ }^{-3}$. The $\mathrm{C}$ content of windrow (coarse debris) was higher $(0.022 \mathrm{gC}$ $\left.\mathrm{cm}_{\text {soil }}^{-3}\right)$ than the row $\left(0.019 \mathrm{gC} \mathrm{cm}_{\text {soil }}^{-3}\right)$, and the free inter-row $\left(0.015 \mathrm{gC} \mathrm{cm}_{\text {soil }^{-3}}\right)$.

We also observed that soil respiration, fine root density, soil humidity, SOM content were consistently higher in the windrow, that dry bulk density was lower (less compaction), that temperature fluctuations were lower. This horizontal variability indicates that management has a measurable impact on SOM distribution, creates gradients and privileged nutrition areas. This can be of major importance during for instance drought stress, for providing a refuge area for root nutrition and water supply and maintaining the production. We argue that the windrow behaves like an "island of fertility for the coconut sustainability", allowing the trees to feed and also to survive during difficult climate conditions (e.g. drought periods).

We did not compare this system with alternative litter management systems yet, although it would be of major interest for helping optimizing the $\mathrm{C}$ sequestration in the soil.

\section{Trend of SOM along a chronosequence}

Lamanda et al. (2004) reported the effect of year after planting (YAP: 1 to > 35 YAP) on surface SOM content. Despite a large variability observed between age classes, there was a significant depletion of almost $20 \%$ during the first twenty years after the coconut planting, as compared to the initial stages of secondary forest. Although this depletion was not catastrophic during the first rotation, it might become serious during the next planting, especially for soils of lesser initial SOM content. In most cases, the depletion occurred during the early stages of planting, indicating that planting might be the crucial phase. Therefore, management techniques during planting are important for $\mathrm{C}$ sequestration (e.g. progressive rather that clear cut, soil cover during planting, etc.). Later on, the stocks appeared to be quite steady, indicating that plantations did not clearly recover $\mathrm{C}$ stocks. It must be reminded too that, apart from SOM, an important $\mathrm{C}$ loss is expected in the total biomass, when comparing the initial forest and the coconut plantation. This can be eventually modulated, keeping some trees within the plantation.

Solutions must be proposed to restore/ maintain the fertility: improved fallow is certainly one, or replanting with legumes, etc. Fallow is traditional in Vanuatu and all the forest are in fact secondary forests. Traditional cultivation techniques, including fallow periods proved to be sustainable, if fallow duration is sufficient.

\section{Ecosystem C stocks in the chronosequence}

The figure 6 gives a rough estimation of the time trend of $\mathrm{C}$ stocks by compartment (plants and soil) along a chronosequence of coconut cultivation after felling the secondary forest. Although this result is mixing experimental and estimated values (symbol *), we believe that in principle, most of the $\mathrm{C}$ stock is to be expected in the soil (in particular for the coconut plantations), and little stock is in the biomass for the coconut plantation (very different from forest). As a matter of fact it sounds highly irrealistic that coconut cultivation would ever recover the initial $\mathrm{C}$ stocks displayed by the forest. The major consequence is that for CDM-C sink projects, only reference baseline ecosystems displaying little initial $\mathrm{C}$ 
stock are worth being targeted before coconut cultivation

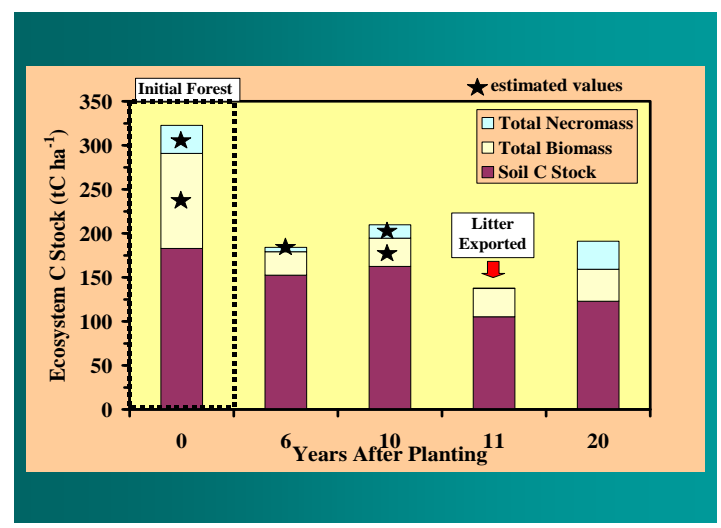

Figure 6: Rough estimation of the time trend of C stocks by compartment (plants and soil) along a chronosequence of coconut cultivation after felling the secondary forest in Santo, Vanuatu. Unpublished results. Mix of experimental and estimated values $(*)$ from literature.

\section{H2O fluxes}

Using same eddy-covariance techniques, evapo-transpiration fluxes were reported by Roupsard et al. (2006). They monitored stand evapo-transpiration by eddy-covariance $(\mathrm{E})$, tree transpiration (T) by heat-dissipative sapflow, soil $(\mathrm{G})$ and stand $(\mathrm{J})$ heat storage during 3 years. On a yearly time step, E represented $40 \%$ of rainfall, the sensible heat flux $(\mathrm{H})$ was $26 \%$ of net radiation and the Bowen ratio was 0.39, all indicating that water availability was close-tooptimum. T represented $68 \%$ of $\mathrm{E}$, close to the $75 \%$ of soil coverage by palms. The seasonal variability was pronounced, driven by radiation and vapour pressure deficit (VPD).

The canopy conductance of coconut palms appeared to be strongly controlled by VPD. Given its constant LAI, its continuous growth and its simple architecture, the coconut palm appears to be an ideal candidate for physiological work and agroforestry modeling, especially for coupling $\mathrm{H}_{2} \mathrm{O}$ fluxes and $\mathrm{C}$ fluxes, e.g. through the water-use efficiency (Roupsard et al, 2007b). Modelling light absorption, $\mathrm{C}$ and $\mathrm{H}_{2} \mathrm{O}$ fluxes
The modeling work is going on (Roupsard et al. 2008), first to estimate light absorption by the canopy of coconuts, according to their structure, age and planting density. Second, to estimate $\mathrm{H}_{2} \mathrm{O}$ and $\mathrm{CO}_{2}$ fluxes. The modelling approach was chosen a Sun-shade model (de Pury and Farquhar 1997), with comparison to a reference 3D architectural model (3DM, (Dauzat et al. 2001); (Mialet-Serra et al. 2001); (Lamanda et al. 2008). The gap fractions of the whole cover, fraction of intercepted PAR (fIPAR), clumping index and leaf orientation derived from LAI-2000 (PCA) were closely matching the simulations 3DM. fIPAR and plant area index (PAI) were compared with the coconut literature and an empirical model was proposed for estimating fIPAR using only age and planting density. The coefficient of extinction, $\mathrm{K}$, was adjusted to 0.33 for the regular range of planting density. Using this simple relationship, it is proposed (Roupsard et al. 2008) and (Roupsard et al. 2007b) to infer PAI, fIPAR, and NPP on large scales, using field surveys of age and density to calibrate remote-sensing vegetation indexes (NDVI, EVI), and light-use efficiency or water-use efficiency information to estimate NPP.

\section{Conclusion and perspectives}

Coconut plantations, when settled in optimal conditions (high fertility, no seasonal drought, selected varieties, optimum age) displayed amongst the highest levels of photosynthesis (Gross Primary Productivity) and of Net Primary Productivity (NPP: the sum of growth and of litter production) encountered in all the forests of the globe, reaching annual GPP and NPP values close to the most productive systems, i.e. the tropical evergreen broadleaved forests. The levels of ecosystem respiration $\left(\mathrm{R}_{\mathrm{e}}\right)$ were consistently very high, and in fine this kind of coconut plantation displayed substantial, but rather regular levels of ecosystem $\mathrm{C}$ balance (Net Ecosystem Productivity, NEP), as compared to tropical forests. NEP is in fact the measurement of $\mathrm{C}$ sequestration, when we ignore all other greenhouse gases and consider solely $\mathrm{CO}_{2}$. 
A major characteristics of coconut trees is that, contrary to dicot trees, coconut does not allocate much of its NPP into permanent structures (stems, coarse roots), but allocates more than $85 \%$ into perishable structures (fruits, leaves, peduncles, fine roots) that will quickly turn into litter, and be respired by the ecosystem or contribute to the build-up of Soil Organic Matter (SOM). This "litter-oriented" fate of C is very peculiar, and cannot be accounted properly using regular forestry inventories of $\mathrm{C}$ sequestration, such as simple evaluation of $\mathrm{C}$ build up in the stems: it will certainly require detailed studies of $\mathrm{C}$ accumulation in the SOM, in addition to the $\mathrm{C}$ accumulated in the biomass and in the necromass (litter).

Key before preparing Kyoto CDM or NonKyoto projects is to gather relevant figures regarding the potential of $\mathrm{C}$ fixation by the

- understand how litter management influences $\mathrm{C}$ sequestration,

- what are the fluxes of other GHG in coconut plantations, according to management

- how different soils, climate influence C cycle and yield

- validate models over different coconut plantations and different climate conditions, especially under drought conditions

- simulate the $\mathrm{C}$ balance on the long term, using past or forecasted climate files

- simulate and validate at the regional scale, with the help of remote sensing

In addition, scientific assessment also brought new insights into some mechanisms of coconut physiology, yield, productivity and ecosystem functioning. Linking these fields together enlightens which factors limit both yield and $\mathrm{C}$ sequestration. ecosystem of reference (baseline to be chosen amongst poor or degraded ecosystems), and by the coconut plantation: $\mathrm{C}$ balance, net primary productivity (NPP), partitioning of the fixed C between organs (especially between semipermanent organs such as stems and nonpermanent organs rapidly turned into litter), partitioning between the coconut and the understorey, impact of the management of the huge amounts of litter, fate of the copra (used for regular oil or for energy oil), production of other greenhouse gases, build-up of $\mathrm{C}$ in the SOM, etc.

It has been argued that scientific assessment of $\mathrm{C}$ fluxes could bring figures for preparing the certification, starting from local measurement, and extrapolating using modelling. It is recommended to the APCC community to invest more into coconut research, especially in order to:

\section{Acknowledgements}

The work was supported by fundings from Cirad (ATP-Carbone, ATP-Reserves, ATP Caresys, CIRAD PhD fellowship for $\mathrm{N}$. Lamanda and I. Mialet-Serra) and the Région Languedoc-Roussillon (France). We are grateful to the government of Vanuatu, to the Department of Agriculture of Vanuatu and to all the staff of the Vanuatu Agricultural Research and Technical Center (VARTC) for having hosted the project in Santo and facilitated every initiative. We express our best gratitude to: Serge Taga, Christian Noel, Antoine Joseph, Thomas Meltecoin, Pedro Toré, Roger Adrien and John Kouback, Vira Tamata, his family and all the farmers of Malo.

\section{References}

Dauzat, J., Rapidel, B. and Berger, A. 2001. Simulation of leaf transpiration and sap flow in virtual plants: model description and application to a coffee plantation in 
Costa Rica. Agric. For. Meteorol., 109(2): $143-160$.

de Pury, D.G.G. and Farquhar, G.D. 1997. Simple scaling of photosynthesis from leaves to canopies without the errors of big-leaf models. Plant Cell and Environment, 20: 537-557.

IPCC, 2007. IPCC Fourth Assessment Report. Available on internet at http://www.ipcc.ch/.

Lamanda, N., Dauzat, J., Jourdan, C., Martin, P. and Malezieux, E. 2008. Using 3D architectural models to assess light availability and root bulkiness in coconut agroforestry systems. Agroforestry Systems, 72: 63-74.

Lamanda, N., Joffre, R., Malézieux, E., Roupsard, O. and Martin, P. 2004a. Soil organic matter in Coconut agroforestry systems. A key to sustainability? [Poster], In: World Congress of Agroforestry, Orlando, USA, 27 June - 2 July 2004.

Lamanda, N., Malezieux, E. and Martin, P. 2004b. Spatial distribution and dynamics of coconut tree (Cocos nucifera L.)-based cropping systems in a Melanesian island (Malo, Vanuatu). Cahiers Agricultures, 13(6): 459-466.

Mialet-Serra, I., Clément-Vidal, A., Roupsard, O., Jourdan, C. and Dingkuhn, M. 2008. Whole-plant adjustments in coconut (Cocos nucifera L.) in response to sinksource imbalance. Tree Physiology (Accepted).

Mialet-Serra, I., Clement, A., Sonderegger, N., Roupsard, O., Jourdan, C., Labouisse, J.P. and Dingkuhn, N. 2005. Assimilate storage in vegetative organs of coconut (Cocos nucifera). Experimental Agriculture, 41(2): 161-174.

Mialet-Serra, I., Dauzat, J. and Auclair, D. 2001. The use of plant architectural models for estimating radiation transfer in coconut- based farming systems. Agroforestry Systems, 53: 141-149.

Navarro, M., Jourdan, C., Sileye, T., Braconnier, S., Mialet-Serra, I., SaintAndre, L., Dauzat, J., Nouvellon, Y., Epron, D., Bonnefond, J.M., Berbigier, P., Rouziere, A., Bouillet, J.P. and Roupsard, O. 2008. Annual and seasonal carbon balance closure in a tropical humid coconut plantation: fruits lag NPP behind GPP. Tree Physiol.(Under revision).

Roupsard, O., Bonnefond, J. and Luyssaert, S. 2007a. Productivity of a tropical plantation of coconut tree (Cocos nucifera, L.), compared with tropical evergreen humid forests. Asiaflux Newsletter, 23: 4-9.

Roupsard, O., Bonnefond, J.M., Irvine, M., Berbigier, P., Nouvellon, Y., Dauzat, J., Taga, S., Hamel, O., Jourdan, C., SaintAndre, L., Mialet-Serra, I., Labouisse, J.P., Epron, D., Joffre, R., Braconnier, S., Rouziere, A., Navarro, M. and Bouillet, J.P. 2006. Partitioning energy and evapotranspiration above and below a tropical palm canopy. Agricultural and Forest Meteorology, 139(3-4): 252-268.

Roupsard, O., Dauzat, J., Nouvellon, Y., Deveau, A., Feintrenie, L., Saint-Andre, L., Mialet-Serra, I., Braconnier, S., Bonnefond, J.-M., Berbigier, P., Epron, D., Jourdan, C., Navarro, M. and Bouillet, J.-P., 2008. Cross-validating Sun-shade and $3 \mathrm{D}$ models of light absorption by a tree-crop canopy. Agricultural and Forest Meteorology, 148(4): 549-564.

Roupsard, O., Dauzat, J., Nouvellon, Y., Jourdan, C., Bonnefond, J.M., Berbigier, P., Navarro, M., Epron, D., Saint-André, L., Mialet-Serra, I., Hamel, O. and Bouillet, J.P., 2007b. Partitioning Light and Water Use Efficiencies (LUE, WUE) between cover tree (Cocos nucifera L.) and grass under-storey, using eddy covariance, LAI-2000 and Net Primary 
Productivity (NPP). In: P.J. Vaast (Editor), Multistrata Agroforestry Systems with Perennial Crops: making ecosystem services count for farmers, consumers and the environment. Agroforestry Systems, Springer, Turrialba, Costa Rica, pp. 8.

Saint-André, L., Roupsard, O., Marsden, C., Thongo M'Bou, A., D'Annunzio, R., De Grandcourt, A., Jourdan, C., Derrien, D., Picard, N., Zeller, B., Harmand, J.-M., Levillain, J., Henry, M., Nouvellon, Y., Deleporte, P., Bouillet, J.-P. and Laclau, J.P. 2007. Literature review on current methodologies to assess $C$ balance in CDM
Afforestation/reforestation projects and a few relevant alternatives for assessing water and nutrient balance, as a complement to carbon sequestration assessments. EU-CARBOAFRICA STREP Project no. 037132 Report (WP 6.4): Quantification, understanding and prediction of carbon cycle, and other GHG gases, in Sub-Saharan Africa. $105 \mathrm{pp}$

\section{Appendix 1}

\begin{tabular}{|c|c|}
\hline Abbreviation & Definition \\
\hline $3 \mathrm{DM}$ & 4D-Architectural Model \\
\hline APCC & Asian and Pacific Coconut Community \\
\hline $\mathrm{C}$ & Carbon \\
\hline $\mathrm{CDM}$ & Clean Development Mechanism \\
\hline $\mathrm{CO}_{2}$ & Carbon dioxide \\
\hline$\Delta \mathrm{C}_{\mathrm{B}}$ & Carbon accumulation in biomass \\
\hline$\Delta \mathrm{C}_{\mathrm{L}}$ & Carbon accumulation in litter \\
\hline$\Delta \mathrm{Cs}$ & Carbon accumulation in soil \\
\hline $\mathrm{DM}$ & Dry Mass \\
\hline DOC & Dissolved Organic Carbon \\
\hline E or ETR & Evapo-transpiration \\
\hline fIPAR & fraction of intercepted PAR \\
\hline GHG & Greenhouse gas \\
\hline GPP & Gross Primary Productivity (Photosynthesis) \\
\hline IPCC & International Panel of experts on Climate Change \\
\hline $\mathrm{K}$ & extinction coefficient for PAR \\
\hline $\mathrm{L}$ & Litter \\
\hline LAI & Leaf Area Index \\
\hline NDVI & Normalized difference vegetation index \\
\hline NEE & Net Ecosystem Exchange (instant C balance) \\
\hline NEP & Net Ecosystem Productivity (integrated C balance of ecosystem) \\
\hline NPP & Net Primary Productivity (growth + mortality) \\
\hline PAI & Plant area index \\
\hline PAR & Photosynthetic Active Radiation \\
\hline PCA & Plant Canopy Analyser (Li-COR, LAI-2000) \\
\hline $\mathrm{R}$ & Respiration \\
\hline $\mathrm{Ra}$ & Respiration (autotrophic) \\
\hline $\operatorname{Re}$ & Respiration (ecosystem) \\
\hline $\mathrm{Rh}$ & Respiration (heterotrophic) \\
\hline SOM & Soil Organic Matter \\
\hline
\end{tabular}


Cord 2008, 24 (1)

\begin{tabular}{|l|l|}
\hline T & Transpiration \\
VARTC & Vanuatu Agricultural Research and Training Center \\
VOC & Volatile Organic Compound \\
VPD & Vapour Pressure Deficit \\
VRD & Vanuatu red dwarf \\
VTT & Vanuatu tall \\
YAP & Year After Planting \\
\hline
\end{tabular}

